the excessive arterial inflow that is important in the pathophysiology of priapism, especially in idiopathic cases. The best treatment is to reduce the arterial supply. ${ }^{5}$

The advantage of arterial embolisation in the control of priapism is that it avoids general anaesthesia and the complications of an operation while, by only temporarily occluding the blood flow, permitting early detumescence with the prospect of normal potency being regained. Priapism should be regarded as a radiological emergency as the sooner embolisation is performed the greater the chance of success.

1 Wear JB, Crummy AB, Munson BO. A new approach to the treatment of priapism. $\mathcal{F}$ Urol 1977;177:252-4.

2 Crummy AB, Ishizuka J, Madsen PO. Post-traumatic priapism: successful treatment with autologous clot embolization. $A \mathcal{F} R$ 1979;133:329-30.

3 Evans LI, Young AE. Internal pudendal arteriography after priapism. Br $\mathcal{F}$ Surg 1973;60:329-30.

- Howe GE, Prentiss RJ, Cole JW, Masters RH. Priapism: a surgical emergency. F Urol 1969;101:576-9.

5 Burt F, Schvimer H, Wallace W. A new concept of management of priapism. F Urol 1960;83:60-1.

(Accepted 18 November 1980)

Department of Radiology, City Hospital, Nottingham NG5 1PB

JAMES M C WAFULA, MB, FRCR, senior registrar

PETER DAVIES, MB, FRCR, consultant radiologist

\section{Trimethoprim in enteric fever}

Co-trimoxazole (trimethoprim-sulphamethoxazole) is of proved efficacy against enteric fever. ${ }^{1}$ Side effects, principally rash, occur in about $8 \%$ of patients ${ }^{2}$ and are usually due to the sulphonamide component, which is less active than trimethoprim against Salmonella typhi and $S$ paratyphi. ${ }^{3}$ Increasing numbers of $S$ typhi strains are resistant to chloramphenicol and also frequently to sulphonamides. This provided a stimulus for studying the efficacy of trimethoprim given alone to patients with enteric fever.

Trimethoprim on its own is now recommended for urinary tract infection. The $B M \mathcal{F}^{4}$ recently commented that it might also be useful against typhoid fever. We have treated eight patients suffering from enteric fever with trimethoprim alone.

\section{Patients, methods, and results}

Seven patients with typhoid fever and one with enteric fever caused by $S$ paratyphi $A$ were treated with trimethoprim. The diagnosis was confirmed by culture of the infecting organism from blood. As all of the patients were ill an injectable form of trimethoprim (not commercially available but kindly supplied by Wellcome Laboratories) was used for the first few days of illness, after which treatment was changed to the oral formulation.* Two patients were given $300 \mathrm{mg}$ trimethoprim 12-hourly, five $200 \mathrm{mg} 12$-hourly, and one, a 5-year-old, $100 \mathrm{mg} \mathrm{12-hourly.} \mathrm{Treatment} \mathrm{was} \mathrm{continued} \mathrm{for} 14$ days and patients remained in hospital for a further 14 days, during which stool and urine specimens were collected for culture at 48-hour intervals. Patients were reviewed in the clinic four weeks after discharge.

Seven patients were cured by a single course of trimethoprim (table). One patient, a 14-year-old boy from whom $S$ typhi resistant to chloramphenicol and ampicillin had been cultured from blood and stool, relapsed 13 days after stopping treatment. His symptoms settled and fever disappeared within

Age, sex, and outcome of treatment with minimum inhibitory concentration of trimethoprim for the eight strains isolated

\begin{tabular}{|c|c|c|c|c|}
\hline $\begin{array}{c}\text { Age } \\
\text { (years) }\end{array}$ & Sex & Organism & $\begin{array}{c}\text { Trimethoprim } \\
\text { minimum } \\
\text { inhibitory } \\
\text { concentration } \\
(\mathrm{mg} / \mathrm{l})\end{array}$ & Outcome \\
\hline $\begin{array}{l}14 \\
5 \\
17 \\
22 \\
48 \\
20 \\
13 \\
23\end{array}$ & $\begin{array}{l}M \\
M \\
F \\
M \\
M \\
M \\
M \\
M\end{array}$ & $\begin{array}{l}\text { S typhi } \\
\text { S typhi } \\
\text { Styphi } \\
\text { Styphi } \\
\text { S paratyphi } A \\
\text { S typhi } \\
\text { S typhi } \\
\text { Styphi }\end{array}$ & $\begin{array}{l}0 \cdot 2 \\
0 \cdot 1 \\
0 \cdot 1 \\
0 \cdot 05 \\
0 \cdot 2 \\
0 \cdot 1 \\
0 \cdot 1 \\
0 \cdot 1\end{array}$ & $\begin{array}{l}\text { Relapse-retreated } \\
\text { Cured } \\
\text { Cured } \\
\text { Cured } \\
\text { Cured } \\
\text { Cured } \\
\text { Cured } \\
\text { Cured }\end{array}$ \\
\hline
\end{tabular}

two days after starting trimethoprim $200 \mathrm{mg}$ 12-hourly. After a 14-day course of trimethoprim six consecutive stools were negative for $S$ typhi, but he had a clinical and microbiological relapse 13 days later. In view of the resistance pattern of the infecting strain he was successfully retreated with a further 12 days of trimethoprim at $300 \mathrm{mg}$ 12-hourly.

Six of the eight patients had six consecutive negative stool cultures after treatment. No side effects or intolerance to either intravenous or orally administered trimethoprim were noted. The table gives the minimum inhibitory concentrations of trimethoprim for the infecting organisms.

\section{Comment}

In all eight patients trimethoprim was well tolerated and effective. Trimethoprim is highly diffusible and is thus well suited to treating enteric fever, which is an intracellular infection. This factor may also be responsible for the encouraging results from tests on stools after treatment, which, as in studies with co-trimoxazole, ${ }^{5}$ were mostly negative. Relapse after treatment occurs in about $15 \%$ of patients with enteric fever regardless of the antibiotic, and it is interesting to note the cure achieved with a second course of trimethoprim in one of our patients.

Our results suggest the need for an extended study of trimethoprim alone in enteric fever, and this is in progress.

We thank Dr L Bernstein, of Wellcome Research Laboratories, for providing trimethoprim for intravenous injection.

1 Geddes AM, Pugh RNH, Nye FJ. Treatment and follow up studies with co-trimoxazole in enteric fever and typhoid carriers. I Antimicrob Chemother 1975;1:51-4.

${ }^{2}$ Lawson DH, Jick H. Adverse reactions to co-trimoxazole in hospitalised medical patients. Am F Med Sci 1978;275:53-7.

${ }^{3}$ Kucers A, Bennett NMcK. The use of antibiotics. 3rd ed. London: William Heinemann, 1979:693.

${ }^{4}$ Anonymous. Bacterial resistance to trimethoprim. $\mathrm{Br} \mathrm{Med} \mathcal{F} 1980 ; 281$ : 571-2.

${ }^{5}$ Ball AP, Farrell ID, Gillett AP, Geddes AM, Clarke PD, Ellis CJ. Enteric fever in Birmingham: clinical features, laboratory investigation and comparison of treatment with pivmecillinam and co-trimoxazole. fournal of Infection 1979;1:353-65.

(Accepted 18 November 1980)

*Intravenous trimethoprim (syraprim; Wellcome Laboratories) is now available on prescription.

Department of Communicable and Tropical Diseases, East Birmingham Hospital, Birmingham B9 5ST

M W MCKENDRICK, MB, MRCP, senior registrar

A M GEDDES, FRCPED, consultant physician

Public Health Laboratory, East Birmingham Hospital, Birmingham B9 5ST

I D FARRELL, PHD, MRCPATH, top-grade microbiologist

WILD CLARY is most blasphemously called Christ's Eye, because it cures diseases of the eye. I could wish for my soul, blasphemy, ignorance, and tyranny, were ceased among physicians, that they may be happy, and I joyful.

It is like the other Clary, but lesser, with many stalks about a foot and a half high. The stalks are square, and somewhat hairy; the flowers of a bluish colour; He that knows the common Clary cannot be ignorant of this. It grows commonly in this nation in barren places; you may find it plentifully, if you look in the fields near Gray's Inn, and near Chelsea. They flower from the beginning of June to the latter end of August.

It is something hotter and drier than the garden Clary is, yet nevertheless under the dominion of the Moon, as well as that; the seeds of it being beat to powder, and drank with wine, is an admirable help to provoke lust. A decoction of the leaves being drank, warms the stomach, and it is a wonder if it should not, the stomach being under Cancer, the house of the Moon. Also it helps digestion, scatters congealed blood in any part of the body. The distilled water hereof cleanses the eyes of redness, waterishness and heat: It is a gallant remedy for dimness of sight, to take one of the seeds of it, and put into the eyes, and there let it remain till it drops out of itself, (the pain will be nothing to speak on,) it will cleanse the eyes of all filthy and putrified matter; and in often repeating it, will take off a film which covers the sight: a handsomer, safer, and easier remedy by a great deal, than to tear it off with a needle. (Nicholas Culpeper (1616-54) The Complete Herbal, 1850.) 